Case Report

\title{
Tubulocystic Renal Cell Carcinoma of the Native Kidney in a Renal Transplant Recipient: A Rare Case Report
}

\author{
Brianna Ruch $\mathbb{D}^{1},{ }^{1}$ Ashley J. Limkemann $(\mathrm{D}),{ }^{1}$ Paulo Garcia $\left(\mathbb{D}^{2},{ }^{2}\right.$ Cameron Benedict, ${ }^{3}$ \\ Gaurav Gupta $\mathbb{C}^{1},{ }^{1}$ Marlon Levy $\mathbb{C}^{1},{ }^{1}$ and Amit Sharma $\mathbb{\circledR}^{1}$ \\ ${ }^{1}$ Hume-Lee Transplant Center, Virginia Commonwealth University, Richmond, VA, USA \\ ${ }^{2}$ Department of Pathology, Virginia Commonwealth University, Richmond, VA, USA \\ ${ }^{3}$ School of Medicine, Virginia Commonwealth University, Richmond, VA 23298, USA \\ Correspondence should be addressed to Amit Sharma; amit.sharma@vcuhealth.org
}

Received 19 December 2019; Revised 12 August 2020; Accepted 29 September 2020; Published 14 October 2020

Academic Editor: Mahzuz Karim

Copyright (C) 2020 Brianna Ruch et al. This is an open access article distributed under the Creative Commons Attribution License, which permits unrestricted use, distribution, and reproduction in any medium, provided the original work is properly cited.

Tubulocystic renal cell carcinoma (TCC) is a rare and newly recognized variant of renal cell carcinoma, which may mimic benign cystic disease of the kidney. To our knowledge, we present the first reported case of a patient who, despite standard preoperative workup, developed TCC of his native kidney soon after receiving kidney transplantation. He was appropriately treated with native nephrectomy and has had no signs of reoccurrence 7 years postoperatively. Given the significant risk of malignancy in renal transplant patients, this case emphasizes the need for close monitoring of native cystic disease before and after transplantation, with low threshold to proceed with surgical intervention.

\section{Introduction}

Tubulocystic renal cell carcinoma (TCC) of the kidney is a rare variant of renal cell carcinoma (RCC), and it was not recognized as a distinct entity by the World Health Organization until 2016 [1]. Literature review only yields approximately 100 reported cases, the majority of which focuses on histologic features and differentiation. There are no reported cases of TCC in transplant recipients, despite the high risk of renal cancer in this population [2]. We report a rare case of tubulocystic renal cell carcinoma occurring in the native left kidney of a renal transplant recipient.

\section{Case Presentation}

A 65-year-old African American male underwent a native right nephrectomy for RCC 25 years ago. Five years later, he began hemodialysis for end-stage renal disease (ESRD) secondary to hypertension and insulin-dependent diabetes. As part of a workup for renal transplant consideration, he underwent contrast-enhanced computed tomography (CT) of the abdomen in 2010 that demonstrated multiple low- attenuation cysts, too small to characterize, and a $3.1 \mathrm{~cm} \times 2.6 \mathrm{~cm}$ nonenhancing lesion in the left renal upper pole consistent with a Bosniak class II renal cyst. Based on these findings, no further follow-up was recommended (Figure 1(a)). Subsequently, he underwent a living-related kidney transplant in 2012 with an immunosuppression regimen consisting of rabbit antithymocyte globulin (thymoglobulin; Genzyme Corp., Cambridge, MA) for induction (day 0 to day 3 at $1.5 \mathrm{mg} / \mathrm{kg}$ ) and maintenance therapy of tacrolimus, mycophenolate mofetil, and a tapering dose of prednisone.

The patient presented to the clinic five months after his transplant with complaints of hematuria and left leg swelling. Abdominal CT scan revealed an enlarging, minimally enhancing hypodense $3.3 \times 3.8 \mathrm{~cm}$ cystic mass, Bosniak class IV, in the upper pole of the native left kidney that was suspicious for RCC (Figure 1(b)). Venous duplex of the left leg demonstrated deep venous thrombosis extending from the popliteal to the left common femoral vein. Patient underwent thrombolysis, placement of the inferior vena cava filter, and systemic anticoagulation followed by an uneventful laparoscopic left radical nephrectomy. Macroscopic 


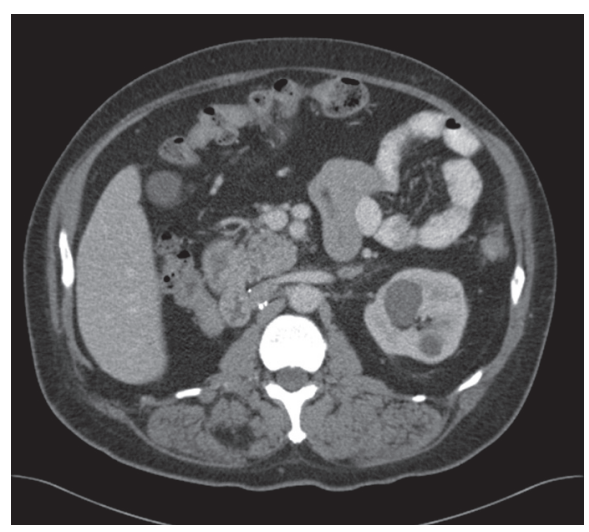

(a)

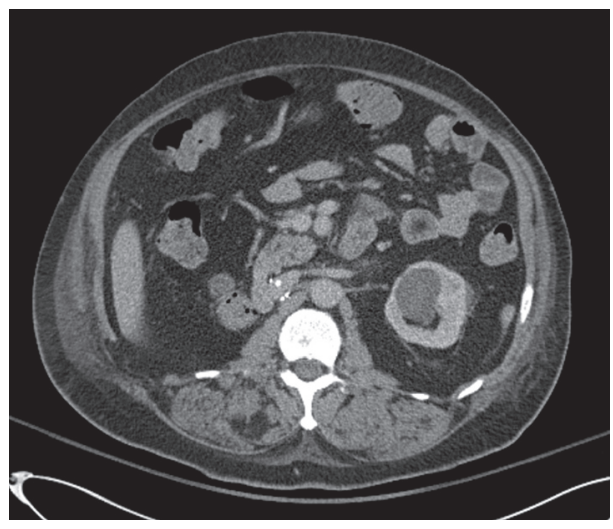

(b)

FIgURE 1: Contrast-enhanced CT scan of the abdomen (a) two years before transplant and (b) five months after transplant. (a) Left kidney showing a $3.1 \times 2.6 \mathrm{~cm}$, nonenhancing, cystic lesion at the upper pole. (b) Enlarged and minimally enhancing $3.3 \times 3.8 \mathrm{~cm}$ mass in the upper pole of the left kidney suspicious for renal cell cancer (white arrow).

evaluation of the specimen showed a $2.3 \times 2.1 \times 2.0 \mathrm{~cm}$ well encapsulated, polycystic mass in the superior pole of the left kidney abutting the pelvis but not invading the renal parenchyma. Immunohistochemical analysis of the neoplastic cyst-lining cells was positive for racemase, CD10, vimentin, and focal positive staining with CK7, as well as negative staining with EMA (Figure 2). The patient was diagnosed with tubulocystic renal cell carcinoma of the kidney, Fuhrman nuclear grade 3, confined to the kidney.

Postoperatively, our patient was followed per the 2018 National Comprehensive Cancer Network (NCCN) guidelines with abdominal imaging at one year and chest imaging annually over three years [3]. He was considered tumor-free based on his last abdominal magnetic resonance imaging in 2014, which showed no recurrent or residual disease. He continued to do well, about seven years after his renal transplant and left native nephrectomy, with a serum creatinine of $1.59 \mathrm{mg} / \mathrm{dL}$ and eGFR $49 \mathrm{~mL} / \mathrm{min} / 1.73 \mathrm{~m}^{2}$. His current immunosuppression consists of tacrolimus $2 \mathrm{mg}$ twice a day, mycophenolate mofetil $750 \mathrm{mg}$ twice a day, and prednisone $10 \mathrm{mg}$ daily.

\section{Discussion}

Cystic lesions of the kidneys may present a diagnostic dilemma in ESRD patients, especially if they are being considered for renal transplantation. Tubulocystic renal cell carcinoma (TCC) of the kidney is a rare, recently recognized entity of renal cell carcinoma (Table 1) [1, 4-7]. To our knowledge, TCC occurring within the native kidney of a renal transplant recipient has not been previously reported.

Tubulocystic renal cell carcinoma is often diagnosed incidentally. However, some patients may present with hematuria, leg swelling, or abdominal pain [8]. It occurs most frequently in the fifth or sixth decades with a strong male predominance (male:female ratio: $7: 1$ ), and approximately $60 \%$ occur in the left kidney [2]. The differential diagnosis of TCC includes other tumors with cystic appearance on imaging, such as multilocular cystic RCC and adult cystic nephroma [7]. It is not uncommon to have TCC described on imaging as cysts with unusual or atypical features [9] and can vary in appearance from Bosniak class II to IV [7]. Macroscopically, TCCs are well-circumscribed lesions comprising small cysts with multiple thin septa that give them a "bubble wrap" appearance. Although relatively indolent, TCC can behave aggressively, and it should be treated with partial or total nephrectomy [10]. Recurrence and/or metastasis occur in less than $10 \%$ of cases.

Renal transplant recipients have an increased risk (0.5-1.0\%) of developing renal cancer when compared to those with ESRD $(0.3 \%)$ and the general population $(0.005 \%)$ [11-14]. The highest incidence of renal cancers occurs in the native kidney but may also occur in the renal allograft or even be transmitted from the donor [15]. This makes renal cancer the third most common solid tumor in transplant recipients and accounts for $10 \%$ of all cancerrelated deaths following renal transplantation [16]. Risk factors for RCC in renal transplant recipients include the length of time on dialysis, the presence of renal cysts, male sex, and African descent $[17,18]$.

Most patients who have been on dialysis more than 3 years will have acquired renal cysts, of which $2 \%$ will develop RCC (11). These renal cysts may be categorized based on their radiologic characteristics (septa, cyst content, and enhancement) into Bosniak I, II, IIF, III, and IV classifications $[19,20]$. The Bosniak classifications stratify malignancy risk, with a recent 2016 review finding malignancy occurring in $9 \%$ of type II cysts, $18 \%$ of type IIF, $51 \%$ of type III, and $86 \%$ of type IV [21]. Standard practice recommends no further intervention for Bosniak I and II, interval imaging follow-up for Bosniak IIF, and surgical intervention for Bosniak III and IV cysts [20].

Despite the increased frequency of renal cysts and RCC in patients with ESRD, there are no widely accepted screening protocols or lower interventional thresholds either before or following transplantation $[11,22,23]$. The lack of screening can be attributed to the relatively high mortality 


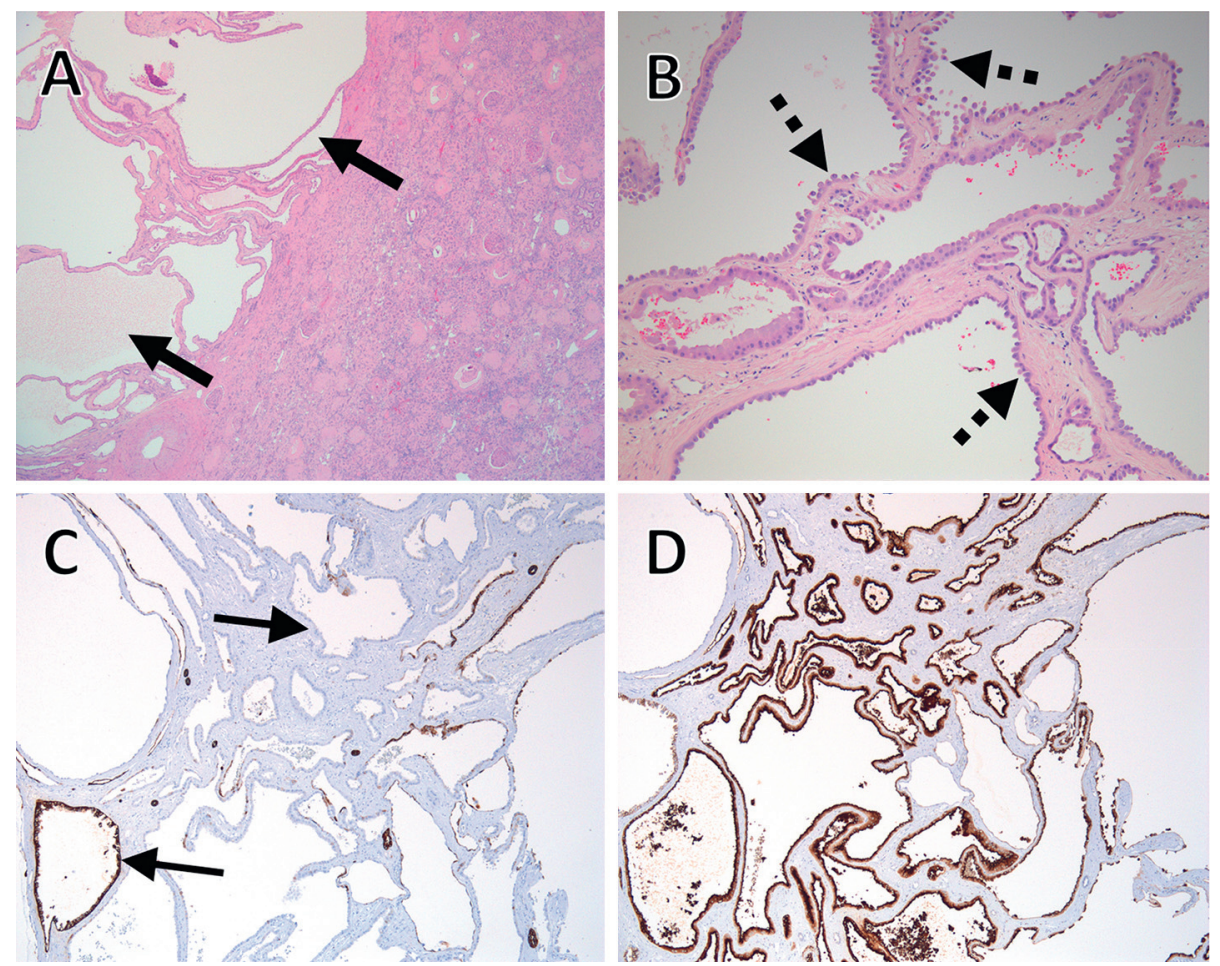

Figure 2: (a) Well-demarcated lesion of small- to intermediate-sized tubules admixed with cystically dilated tubules (solid thick arrows). (b) Tubules and cysts comprising a single epithelial layer of flat to hobnail-shaped cells with abundant, pink cytoplasm and large nuclei with prominent nucleoli (dashed thick arrows). The stroma was fibrotic and paucicellular, while mitotic activity was low to absent. No papillary architecture or epithelial cell clearing was observed. (c) Immunohistochemical stain for CK7 showed patchy reactivity (thin solid arrows) in the lesional areas. (d) CD10 showed strong reactivity.

TABLe 1: Common subtypes of renal cell carcinoma [3-5].

\begin{tabular}{|c|c|c|c|c|c|}
\hline Renal cell carcinoma & Associations & Imaging & Morphologic characteristics & Behavior & Incidence \\
\hline Clear cell & $\begin{array}{l}\text { Patients }>50 \text { years } \\
\text { Von Hippel-Lindau } \\
\text { tuberous sclerosis }\end{array}$ & $\begin{array}{l}\text { Hypervascular } \\
\text { Heterogeneous } \\
\text { (hemorrhage, necrosis, } \\
\text { or cysts) } \\
\text { Originates from the } \\
\text { renal cortex }\end{array}$ & $\begin{array}{l}\text { Cells with clear cytoplasm, } \\
\text { prominent nucleoli, and extensive } \\
\text { intricate branching vasculature, } \\
\text { arranged in a nested architectural } \\
\text { pattern. }\end{array}$ & Aggressive & $75 \%$ \\
\hline Papillary cell & $\begin{array}{c}\text { Patients }>50 \text { years } \\
\text { Hereditary papillary } \\
\text { RCC } \\
\text { End-stage renal }\end{array}$ & $\begin{array}{c}\text { Hypovascular } \\
\text { Homogeneous } \\
\text { More common to be } \\
\text { bilateral or multifocal }\end{array}$ & $\begin{array}{l}\text { Neoplastic cells arranged in discrete } \\
\text { papillary fronds with fibrovascular } \\
\text { cores and can also be in a papillary- } \\
\text { trabecular or papillary-solid } \\
\text { architectural pattern. }\end{array}$ & Aggressive & $10-15 \%$ \\
\hline Chromophobe & $\begin{array}{l}\text { Patients }>50 \text { years } \\
\text { Birt-Hogg-Dube } \\
\text { syndrome }\end{array}$ & $\begin{array}{l}\text { Hypovascular spoke- } \\
\text { wheel contrast } \\
\text { enhancement } \\
\text { Indistinguishable from } \\
\text { oncocytomas } \\
\end{array}$ & $\begin{array}{l}\text { Smaller eosinophilic and larger pale } \\
\text { neoplastic cells with wrinkled nuclei } \\
\text { and perinuclear halos arranged in a } \\
\text { predominantly solid architectural } \\
\text { pattern. }\end{array}$ & $\begin{array}{c}\text { Favorable, low } \\
\text { mortality }\end{array}$ & $5-11 \%$ \\
\hline Collecting duct & $\begin{array}{l}\text { Male-to-female ratio: } \\
\qquad 2: 1 \\
\text { Patients: fourth and } \\
\text { fifth decades }\end{array}$ & $\begin{array}{l}\text { Heterogeneous } \\
\text { (necrosis, hemorrhage, } \\
\text { and calcification) } \\
\text { infiltrative growth } \\
\text { Originates from the } \\
\text { medullary center }\end{array}$ & $\begin{array}{l}\text { High-grade neoplastic cells with } \\
\text { variable architectural patterns } \\
\text { ranging from cribriform, papillary, } \\
\text { solid, and tubular. Prominent } \\
\text { stromal desmoplasia. }\end{array}$ & $\begin{array}{l}\text { Very } \\
\text { aggressive, } 1 / 3 \\
\text { metastatic on } \\
\text { diagnosis }\end{array}$ & $1 \%$ \\
\hline
\end{tabular}


TABLE 1: Continued.

\begin{tabular}{|c|c|c|c|c|c|}
\hline Renal cell carcinoma & Associations & Imaging & Morphologic characteristics & Behavior & Incidence \\
\hline Renal medullary & $\begin{array}{l}\text { Associated with } \\
\text { sickle cell trait } \\
\text { Male-to-female ratio: } \\
\qquad 2: 1 \\
\text { Mean age: } 22 \text { years }\end{array}$ & $\begin{array}{c}\text { Hypovascular } \\
\text { Heterogeneous } \\
\text { (hemorrhage and } \\
\text { necrosis) } \\
\text { Liver and lung } \\
\text { metastasis }\end{array}$ & $\begin{array}{l}\text { High-grade eosinophilic, neoplastic } \\
\text { cells in varying architectural } \\
\text { patterns. Cribriform pattern is the } \\
\text { most common. Prominent } \\
\text { desmoplastic stroma. }\end{array}$ & $\begin{array}{c}\text { Very } \\
\text { aggressive } \\
\text { Mean survival: } \\
15 \text { weeks }\end{array}$ & $1 \%$ \\
\hline Multiloculated cystic & $\begin{array}{l}\text { Mean age: } 50 \text { years } \\
\text { Predominate in } \\
\text { women with male- } \\
\text { to-female ratio } 1: 4\end{array}$ & $\begin{array}{l}\text { Largely cystic lesions, } \\
\quad<25 \% \text { solid }\end{array}$ & $\begin{array}{l}\text { Multiple cysts with thin septa, lined } \\
\text { by clear cells. }\end{array}$ & $\begin{array}{l}\text { Indolent, } \\
\text { favorable } \\
\text { prognosis }\end{array}$ & $\begin{array}{l}\text { Less than } \\
1 \%\end{array}$ \\
\hline Tubulocystic & $\begin{array}{c}\text { Patients }>50 \text { years } \\
\text { Male-to-female ratio: } \\
7: 1\end{array}$ & $\begin{array}{l}\text { Predominately cystic } \\
\text { lesion with thin septa }\end{array}$ & $\begin{array}{l}\text { Purely tubular and cystic growth } \\
\text { pattern. Cysts lined by a single layer } \\
\text { of neoplastic cells with hobnail } \\
\text { appearance. }\end{array}$ & $\begin{array}{l}\text { Largely } \\
\text { indolent, rare } \\
\text { reports of } \\
\text { metastatic } \\
\text { disease } \\
\end{array}$ & $\begin{array}{l}\text { Rare (less } \\
\text { than } 100 \\
\text { cases } \\
\text { reported) }\end{array}$ \\
\hline
\end{tabular}

associated with ESRD and the fact that screening has not been shown to significantly increase life expectancy except when performed in younger patients. Currently, many dialysis centers will only perform routine renal screening on patients who are on the transplant waitlist [22]. For ESRD patients on the renal transplant waitlist (or undergoing evaluation) that have suspicious or complex cystic lesions, we suggest a nephrectomy in (a) young patients with a history of long-standing dialysis, (b) prior history of renal cell carcinoma in the contralateral kidney, and (c) those who may be expected to follow-up with their local nephrologists for long-term posttransplant care.

We conclude that tubulocystic renal cell carcinoma is a distinct entity of RCC. This rare case report highlights the elevated risk of developing renal cancer in transplant recipients, especially those with known renal cystic disease prior to transplantation. Therefore, such high-risk recipients should undergo either close postoperative monitoring, with annual surveillance ultrasound [16], or undergo a native nephrectomy prior to transplantation.

\section{Abbreviations}

TCC: Tubulocystic renal cell carcinoma

RCC: Renal cell carcinoma

ESRD: End-stage renal disease

CT: Computed tomography

CD: Cluster of differentiation

CK: Cytokeratin

EMA: Epithelial membrane antigen.

\section{Conflicts of Interest}

The authors declare that they have no conflicts of interest.

\section{Acknowledgments}

The authors thank Dr. Jinxing $\mathrm{Yu}$ for his assistance in reading the radiological images.

\section{References}

[1] H. Moch, A. L. Cubilla, P. A. Humphrey, V. E. Reuter, and T. M. Ulbright, "The 2016 WHO classification of tumours of the urinary system and male genital organs-part A: renal, penile, and testicular tumours," European Urology, vol. 70, no. 1, pp. 93-105, 2016.

[2] J. S. Bhullar, N. Varshney, A. K. Bhullar, and V. K. Mittal, “A new type of renal cancer-tubulocystic carcinoma of the kidney: a review of the literature," International Journal of Surgical Pathology, vol. 22, no. 4, pp. 297-302, 2014.

[3] National Comprehensive Cancer Network, Kidney Cancer (Version 4.2018), National Comprehensive Cancer Network, Plymouth Meeting, PA, USA, 2018, https://www2.tri-kobe. org/nccn/guideline/urological/english/kidney.pdf.

[4] S. R. Prasad, P. A. Humphrey, J. R. Catena et al., "Common and uncommon histologic subtypes of renal cell carcinoma: imaging spectrum with pathologic correlation," Radiographics, vol. 26, no. 6, pp. 1795-1806, 2006.

[5] V. F. Muglia and A. Prando, "Renal cell carcinoma: histological classification and correlation with imaging findings," Radiologia Brasileira, vol. 48, no. 3, pp. 166-174, 2015.

[6] J. J. Hsieh, M. P. Purdue, S. Signoretti et al., "Renal cell carcinoma," Nature Reviews. Disease Primers, vol. 3, Article ID 17009, 2017.

[7] Y. Honda, Y. Nakamura, K. Goto et al., "Tubulocystic renal cell carcinoma: a review of literature focused on radiological findings for differential diagnosis," Abdominal Radiology, vol. 43, no. 7, pp. 1540-1545, 2018.

[8] I. Banerjee, S. S. Yadav, V. Tomar, S. Yadav, and S. Talreja, "Tubulocystic renal cell carcinoma: a great imitator," Reviews in Urology, vol. 18, no. 2, pp. 118-21, 2016.

[9] J. R. Srigley and B. Delahunt, "Uncommon and recently described renal carcinomas," Modern Pathology, vol. 22, no. S2, pp. S2-S23, 2009.

[10] Y. Ishibashi, T. Koie, N. Fujita et al., "Tubulocystic renal cell carcinoma in the left kidney: a case report," Journal of Medical Case Reports, vol. 8, p. 265, 2014.

[11] A. Chewcharat, C. Thongprayoon, T. Bathini et al., "Incidence and mortality of renal cell carcinoma after kidney transplantation: a meta-analysis," Journal of Clinical Medicine, vol. 8, no. 4, p. 530, 2019.

[12] S. Karami, E. L. Yanik, L. E. Moore et al., "Risk of renal cell carcinoma among kidney transplant recipients in the United 
States," American Journal of Transplantation, vol. 16, no. 12, pp. 3479-3489, 2016.

[13] B. L. Kasiske, J. J. Snyder, D. T. Gilbertson, and C. Wang, "Cancer after kidney transplantation in the United States," American Journal of Transplantation, vol. 4, no. 6, pp. 905913, 2004.

[14] P. Maisonneuve, L. Agodoa, R. Gellert et al., "Cancer in patients on dialysis for end-stage renal disease: an international collaborative study," The Lancet, vol. 354, no. 9173, pp. 93-99, 1999.

[15] C. Morath, M. Mueller, H. Goldschmidt, V. Schwenger, G. Opelz, and M. Zeier, "Malignancy in renal transplantation," Journal of the American Society of Nephrology, vol. 15, no. 6, pp. 1582-1588, 2004.

[16] G. M. Frascà, S. Sandrini, L. Cosmai et al., "Renal cancer in kidney transplanted patients," Journal of Nephrology, vol. 28, no. 6, pp. 659-668, 2015.

[17] A. Goh and A. Vathsala, "Native renal cysts and dialysis duration are risk factors for renal cell carcinoma in renal transplant recipients," American Journal of Transplantation, vol. 11, no. 1, pp. 86-92, 2011.

[18] L. A. Hickman, D. Sawinski, T. Guzzo, and J. E. Locke, "Urologic malignancies in kidney transplantation," American Journal of Transplantation, vol. 18, no. 1, pp. 13-22, 2018.

[19] M. A. Bosniak, "The current radiological approach to renal cysts," Radiology, vol. 158, no. 1, pp. 1-10, 1986.

[20] R. Boissier, I. Ouzaid, F. X. Nouhaud et al., "Long-term oncological outcomes of cystic renal cell carcinoma according to the Bosniak classification," International Urology and Nephrology, vol. 51, no. 6, pp. 951-958, 2019.

[21] I. G. Schoots, K. Zaccai, M. G. Hunink, and P. C. M. S. Verhagen, "Bosniak classification for complex renal cysts reevaluated: a systematic review," Journal of Urology, vol. 198, no. 1, pp. 12-21, 2017.

[22] J. L. Holley, "Screening, diagnosis, and treatment of cancer in long-term dialysis patients," Clinical Journal of the American Society of Nephrology, vol. 2, no. 3, pp. 604-610, 2007.

[23] A. Schwarz, S. Vatandaslar, S. Merkel, and H. Haller, "Renal cell carcinoma in transplant recipients with acquired cystic kidney disease," Clinical Journal of the American Society of Nephrology, vol. 2, no. 4, pp. 750-756, 2007. 